\title{
Magnetic Properties of $\mathrm{TbCu}_{7}$ Type Sm-Fe-Co-Ti-Zr-Y System Nitrides
}

\author{
H. Yamamoto and M. Tajima
}

School of Science and Technology, Meiji Univ., 1-1-1, Higashimita, Tama-ku, Kawasaki 214-8571, Japan

Experiments were carried out to investigate the effects of composition, heat-treatment, and nitrogenation conditions on the magnetic properties of Sm-Fe-Co-Ti-Zr-Y-N compounds with a $\mathrm{TbCu}_{7}$-type structure. The optimum preparation conditions for the compounds were: composition: $\left\{\mathrm{Sm}_{10}\left(\mathrm{Fe}_{0.9} \mathrm{Co}_{0.1}\right)_{88.7} \mathrm{Ti}_{0.3} \mathrm{Zr}_{0.5} \mathrm{Y}_{0.5}\right\}_{85.6} \mathrm{~N}_{14.4}$, roller velocity: $50 \mathrm{~m} / \mathrm{s}$, heat treatment: $660^{\circ} \mathrm{C}$ for $60 \mathrm{~min}$ in high-purity $\mathrm{Ar}$ gas, and nitrogenation conditions: $420^{\circ} \mathrm{C}$ for $10 \mathrm{~h}$ in high-purity $\mathrm{N}_{2}$ gas. Typical magnetic properties of the obtained compound powders were: $J_{\mathrm{r}}=0.98 \mathrm{~T}, H_{\mathrm{cJ}}=751.5 \mathrm{kA} / \mathrm{m}$, $H_{\mathrm{cB}}=544.7 \mathrm{kA} / \mathrm{m},(B H)_{\max }=147.0 \mathrm{~kJ} / \mathrm{m}^{3}(18.5 \mathrm{MGOe})$, and $T_{\mathrm{c}}=510{ }^{\circ} \mathrm{C}$. We found that a sample made from these compound powders was an exchange spring magnet from the recoil loops of the hysteresis curves, X-ray diffraction patterns, and $\sigma$-T (Magnetization-Temperature) curves. The value of $(B H)_{\max }$ for an isotropic compression-molding bonded magnet prepared by using $\left\{\mathrm{Sm}_{10}\left(\mathrm{Fe}_{0.9} \mathrm{Co}_{0.1}\right)_{88.7} \mathrm{Ti}_{0.3} \mathrm{Zr}_{0.5} \mathrm{Y}_{0.5}\right\}_{85.6} \mathrm{~N}_{14.4}$ powder was $92.7 \mathrm{~kJ} / \mathrm{m}^{3}$ (11.7 MGOe), when the density of the bonded magnet was $6.08 \mathrm{Mg} / \mathrm{m}^{3}$. The average reversible temperature coefficient of $J_{\mathrm{r}}$ was $\alpha\left(J_{\mathrm{r}}\right)_{\text {ave. }}=$ $-0.05 \% /{ }^{\circ} \mathrm{C}$, and the temperature coefficient of $H_{\mathrm{cJ}}$ in a range from 25 to $125^{\circ} \mathrm{C}$ obtained by linear extrapolation was $\alpha\left(H_{\mathrm{cJ}}\right)$ $=-0.46 \% /{ }^{\circ} \mathrm{C}$.

Keywords: Sm-Fe-Co-Ti-Zr-Y system nitrides, $\mathrm{TbCu}_{7}$-type structure, magnetic properties, nitrogenation, bonded magnet

\section{$\mathrm{TbCu}_{7}$ 型構造 $\mathrm{Sm}-\mathrm{Fe}-\mathrm{Co}-\mathrm{Ti}-\mathrm{Zr}-\mathrm{Y}$ 系窒化化合物磁石の磁気特性}

\author{
山元 洋 - 田 嶋 允 順 \\ 明治大学理工学部，川崎市多摩区東三田 1-1-1（下214-8571）
}

\begin{abstract}
1. 緒 言
近年, 液体急冷法を用いた $\mathrm{SmFe}_{7}$ 系窒化化合物の研究は 盛んに行われている ${ }^{1-13)}$. 先に著者らは $\mathrm{Sm}-\mathrm{Fe}-\mathrm{Co}-\mathrm{Cr}$ 系化 合物に Y を添加することにより，保磁力が上昇すること を報告した ${ }^{11)}$. 本実験は高性能な $\mathrm{TbCu}_{7}$ 型構造 $\mathrm{SmFe}_{7}$ 系 窒化化合物磁石を開発する目的で, 著者らが先に高性能な 特性が得られた Sm-Fe- Co-Ti-Zr 系化合物 ${ }^{10)}$ を基本に Y 添 加し, 片ロール液体急冷法を用い試料を作製し, 組成, 熱 処理, 窒化条件等がこれらの窒化化合物に与える影響を詳 細に実験し, その磁気的, 物理的特性について, 今回詳細 に検討したので報告する. また, これらの試料の粉末を用 いてボンド磁石を作製し, それらの諸特性についても報告 する。
\end{abstract}

\section{2. 実 験 方 法}

実験に用いた試料は $\mathrm{Sm}_{10}\left(\mathrm{Fe}_{0.9} \mathrm{Co}_{0.1}\right)_{89.2-\mathrm{x}} \mathrm{Ti}_{0.3} \mathrm{Zr}_{0.5} \mathrm{Y}_{\mathrm{x}}(\mathrm{at} \%)$ 組成において $\mathrm{x}=0.0 \sim 2.0$ まで変化させたもので,これら母 合金は真空高周波炉にて各試料 $2.5 \mathrm{~kg}$ で溶解鋳造した.こ れら合金は組成分析を行い, 確認された組成で実験を行っ た．急冷薄帯の作製は，高純度 Ar ガス雾囲気中において 片ロール液体急冷法により, 周速度 $50 \mathrm{~m} / \mathrm{s}$ 一定で行った。 その後, 作製した急冷薄帯を 32 75 $\mu \mathrm{m}$ に粉砕した. 熱処 理は, 赤外線ゴールドイメージ炉を用い純度 $99.998 \% \mathrm{Ar}$ ガス雰囲気中で熱処理温度 $640 \sim 700{ }^{\circ} \mathrm{C}$ の温度範囲で熱処 理時間 $60 \mathrm{~min}$ 一定として行い, 窒化処理は熱処理から所 定の温度に下げ, 引き続き $99.9998 \% \mathrm{~N}_{2}$ ガス雾囲気中で窒
化温度 380 440 ${ }^{\circ} \mathrm{C}$ の温度範囲で窒化時間を 5 20 h とした. なお, 粉末の磁気特性は, 反磁界補正せず, 振動試料型磁 力計 (VSM)を用いて測定した。 また, 結晶構造は, CuKa を用いた粉末 X 線回折法 (XRD)により調べた。試料の組 織は透過型電子顕微鏡 (TEM)により観察した。さらに得 られた試料を用い, 結合剂としてエポキシ樹脂を $2.5 \mathrm{wt} \%$ 加え, プレス圧 $980 \mathrm{MPa}$ で圧縮成形したのち, $150{ }^{\circ} \mathrm{C} \times 1 \mathrm{~h}$ の硬化処理を施してボンド磁石を作製した。 なお, ボンド 磁石の磁気特性は高感度自記磁束計を用いて測定した。

\section{3. 実験 結果ならびに考察 \\ 3.1 組成, 窒化条件等の磁気特性に及ぼす影響}

まず最初に, $\mathrm{Sm}_{10}\left(\mathrm{Fe}_{0.9} \mathrm{Co}_{0.1}\right)_{89.2-\mathrm{x}} \mathrm{Ti}_{0.3} \mathrm{Zr}_{0.5} \mathrm{Y}_{\mathrm{x}}$ 組成において $\mathrm{Y}$ 量 $\mathrm{x}=0,0.3,0.5,0.7,1.0,1.5,2.0 \mathrm{at} \%$ と変化させたとき, 試料の磁気特性にどのような影響を与えるかについて実 験検討した. Fig. 1 は $\mathrm{Sm}_{10}\left(\mathrm{Fe}_{0.9} \mathrm{Co}_{0.1}\right)_{89.2-\mathrm{x}} \mathrm{Ti}_{0.3} \mathrm{Zr}_{0.5} \mathrm{Y}_{\mathrm{x}}$ 組成に おいて $\mathrm{Y}$ 量を $\mathrm{x}=0 \sim 2.0$ at $\%$ と変化させたそれぞれの試料 に熱処理条件 $660{ }^{\circ} \mathrm{C} \times 60 \mathrm{~min}$, 窒化処理条件 $420{ }^{\circ} \mathrm{C} \times 10 \mathrm{~h}$ 一 定として処理した時の磁気特性を示したものである.この 図からわかるように, $\mathrm{H}_{\mathrm{cJ}}$ は $\mathrm{x}$ の増加にともない増加した。 $\sigma_{\mathrm{r}}$ は $\mathrm{x}=0 \sim 0.5 \mathrm{at} \%$ では若干増加していき, $\mathrm{x}=0.5 \mathrm{at} \%$ の き最大值をとり, その後減少した. $(\mathrm{BH})_{\max }$ は $x=0 \sim 0.5 \mathrm{at} \%$ では徐々に増加していき, $\mathrm{x}=0.5 \mathrm{at} \%$ のとき最大值をとり, その後減少した。 以上の結果より, $\mathrm{Y}$ 量 $\mathrm{x}=0.5 \mathrm{at} \%$ の時に 最高の $(\mathrm{BH})_{\max }$ を示したので，以後の実験では $\mathrm{Sm}_{10}\left(\mathrm{Fe}_{0.9} \mathrm{Co}_{0.1}\right)_{88.7} \mathrm{Ti}_{0.3} \mathrm{Zr}_{0.5} \mathrm{Y}_{0.5}$ 組成を中心に詳細な実験を 
における, Nd-Fe-B 系磁石の結晶粒成長による残留磁化の

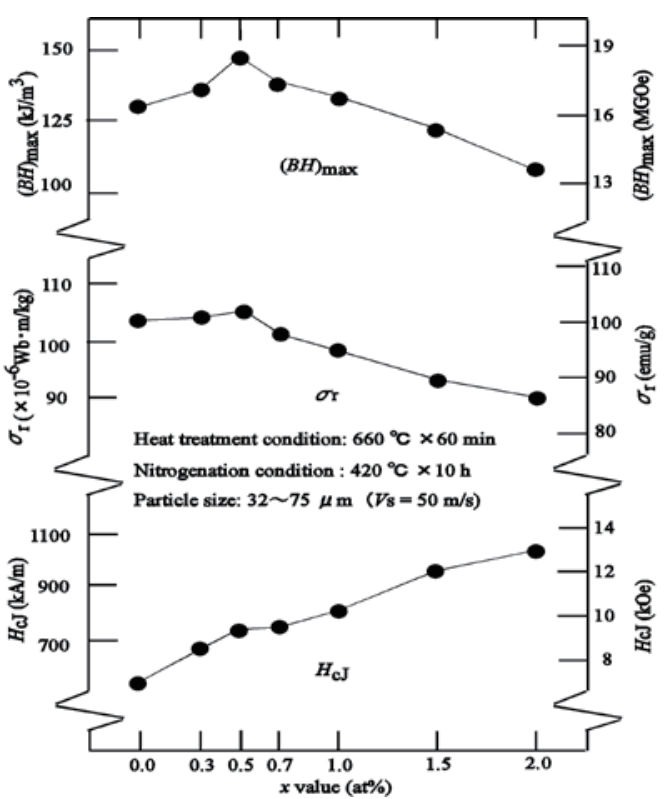

減少と緩やかな保磁力の増加と同様に考えられ, 粒子間相 互作用が弱まった結果と思われる。また $(\mathrm{BH})_{\max }$ において も $660{ }^{\circ} \mathrm{C}$ のき最も良好な磁気特性を示したことから, 以 後の熱処理温度を $660{ }^{\circ} \mathrm{C}$ とて実験検討を行った。

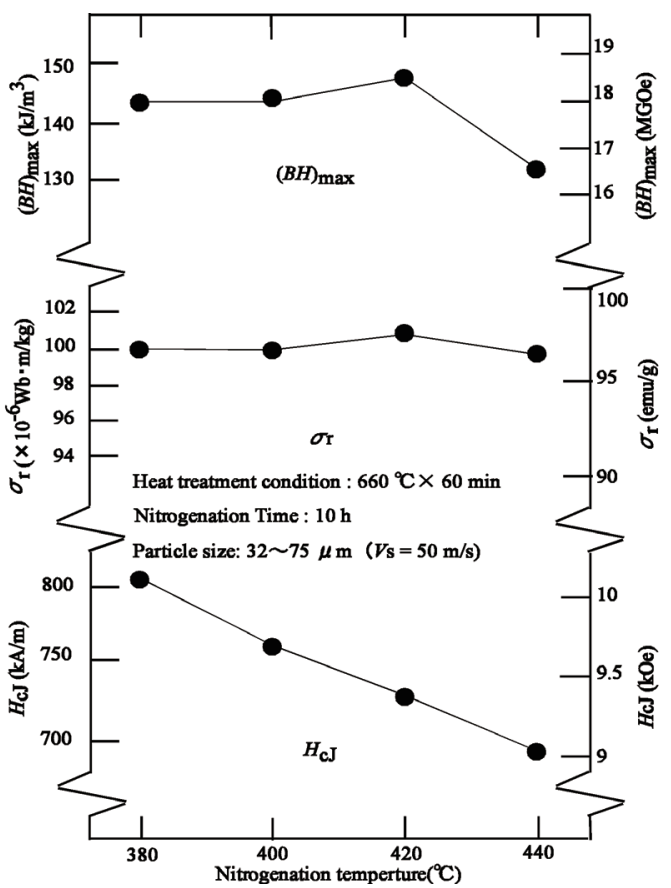

Fig. 3 Effect of nitrogenation temperature on magnetic properties of $\mathrm{Sm}_{10}\left(\mathrm{Fe}_{0.9} \mathrm{Co}_{0.1}\right)_{88.7} \mathrm{Ti}_{0.3} \mathrm{Zr}_{0.5} \mathrm{Y}_{0.5}$ nitrides.

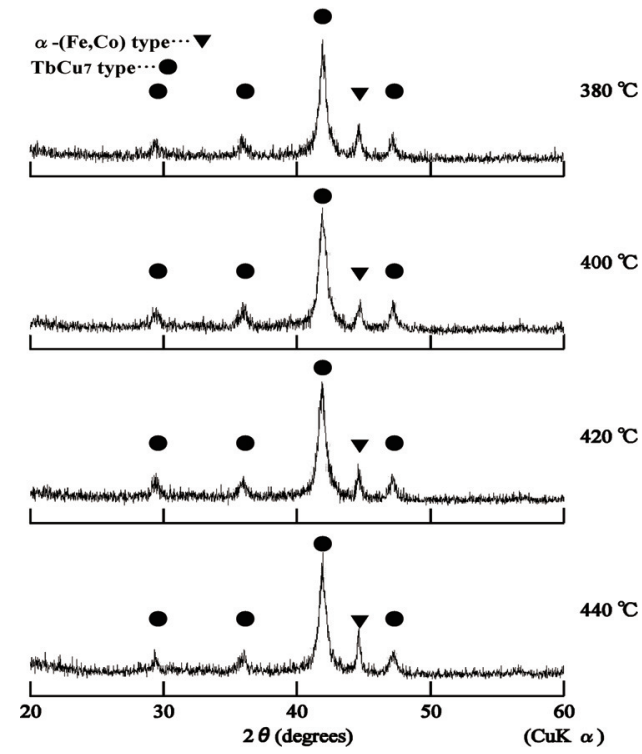

Fig. 4 X-ray diffraction patterns of $\mathrm{Sm}_{10}\left(\mathrm{Fe}_{0.9} \mathrm{Co}_{0.1}\right)_{88.7}$ $\mathrm{Ti}_{0.3} \mathrm{Zr}_{0.5} \mathrm{Y}_{0.5}$ nitrides. 化処理条件 $420{ }^{\circ} \mathrm{C} \times 10 \mathrm{~h}$ とし, 熱処理時間 $60 \mathrm{~min}$ 一定で 窒化前の熱処理温度を $640 \sim 700{ }^{\circ} \mathrm{C}$ と変化させたときの磁 気特性を示したものである。この図より， $\mathrm{H}_{\mathrm{cJ}}$ は熱処理温 度が上昇するとともに増加していき， $\sigma_{\mathrm{r}}$ は $640{ }^{\circ} \mathrm{C}$ から $660{ }^{\circ} \mathrm{C}$ までは若干増加し, $660{ }^{\circ} \mathrm{C}$ で最高值をとった後, $700{ }^{\circ} \mathrm{C}$ にかけ徐々に減少した。この熱処理温度の上昇によ って $\mathrm{H}_{\mathrm{cJ}}$ が上昇し， $\sigma_{\mathrm{r}}$ が低下寸る現象は, 福永 ${ }^{14)}$ の報告

次に窒化処理条件について検討した。Fig. 3 は, $\mathrm{Sm}_{10}\left(\mathrm{Fe}_{0.9} \mathrm{Co}_{0.1}\right)_{88.7} \mathrm{Ti}_{0.3} \mathrm{Zr}_{0.5} \mathrm{Y}_{0.5}$ 組成において, 熱処理条件を $660{ }^{\circ} \mathrm{C} \times 60 \mathrm{~min}$, 窒化処理時間を $10 \mathrm{~h}$ で一定とし, 窒化処 理温度を 380 440 ${ }^{\circ} \mathrm{C}$ 変化させたときの磁気特性を示し たものである。この図より， $\mathrm{H}_{\mathrm{cJ}}$ は窒化温度の上昇と共に 
徐々に減少し. $\sigma_{\mathrm{r}},(\mathrm{BH})_{\max }$ ともに窒化処理温度 $420{ }^{\circ} \mathrm{C}$ で 最高值をとりその後減少した. 又 Fig.4 はこの処理条件下 での X 線回折図を示したものである.この X 線回折図に おいて特に保磁力が窒化処理温度の上昇とともに減少す る原因については明確ではないが, 窒化処理温度 $420{ }^{\circ} \mathrm{C}$ 以上で軟質磁性相である $\alpha-(\mathrm{Fe}, \mathrm{Co})$ 相の強度が大きくなっ ていることから, $\mathrm{Sm}(\mathrm{Fe}, \mathrm{Co})_{7}$ 窒化物の減少が保磁力の減少 の原因と思われる.これらのナノコンポジット磁石につい て, Fischer ら 15) と Bauer ら ${ }^{16)}$ はナノコンポジット $\mathrm{Nd}_{2} \mathrm{Fe}_{14} \mathrm{~B} / \alpha-\mathrm{Fe}$ 磁石について, $\alpha$ - $\mathrm{Fe}$ の含有量, 粒子の大き さ等について詳細に検討し， $\alpha$ - Fe の量によってはヒステ リシスの角型, 保磁力が低下寸ることを指摘している. 又 日高ら ${ }^{6}$ は $(\mathrm{SmZr}) \mathrm{Fe}_{7} \mathrm{~N}_{\mathrm{x}}+\alpha-\mathrm{Fe}$ ナノコンポジット磁石で $\alpha-\mathrm{Fe}$ の含有量と磁気特性について調べ, $\alpha$-Fe が $16 \%$ 21\%の範 囲で少量の $\alpha-\mathrm{Fe}$ 相の違いで, $\alpha-\mathrm{Fe}$ の多い方が保磁力が落 ちることを指摘している. 以上を参考にすると, X 線回折 図において $\alpha-(\mathrm{Fe}, \mathrm{Co})$ 相が増加していることが， $\alpha-(\mathrm{Fe}, \mathrm{Co}) /$ $\mathrm{Sm}(\mathrm{Fe}, \mathrm{Co})_{7}$ の比を取っても最終的には $\mathrm{Sm}(\mathrm{Fe}, \mathrm{Co})_{7}$ 相の減 少に繋がるので，保磁力が減少する一因と思われる。

以上の結果から, 窒化処理温度 $420{ }^{\circ} \mathrm{C}$ のき最も良好 な磁気特性を示したことから, 以後窒化処理温度を $420{ }^{\circ} \mathrm{C}$ とて実験検討を行った.

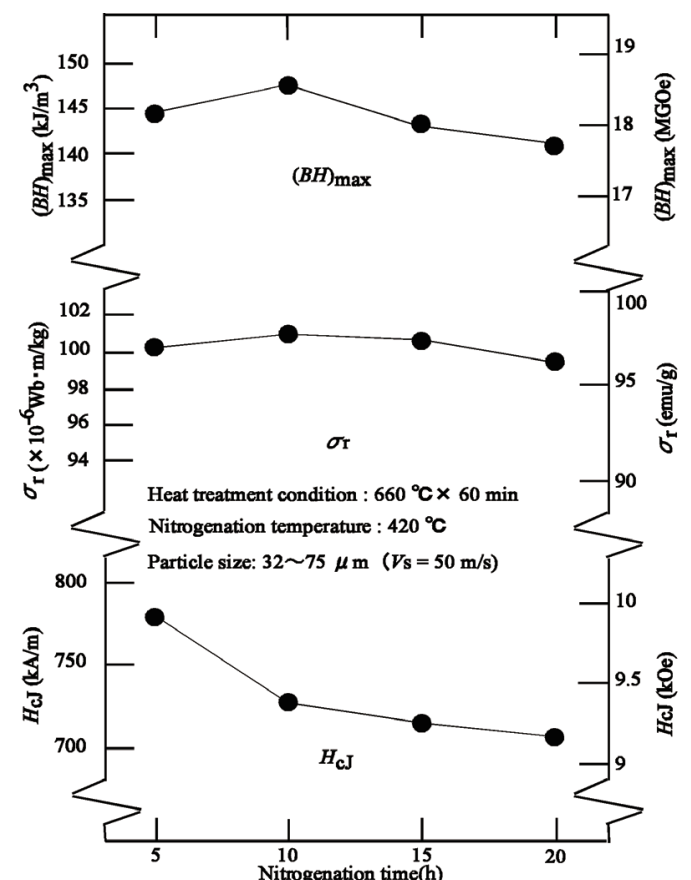

Fig. 5 Effect of nitrogenation time on magnetic properties of $\mathrm{Sm}_{10}\left(\mathrm{Fe}_{0.9} \mathrm{Co}_{0.1}\right)_{88.7} \mathrm{Ti}_{0.3} \mathrm{Zr}_{0.5} \mathrm{Y}_{0.5}$ nitrides.

Fig. 5 は最適組成において, 熱処理条件を $660{ }^{\circ} \mathrm{C} \times 60 \mathrm{~min}$, 窒化処理温度を $420{ }^{\circ} \mathrm{C}$ 一定とし, 窒化処理時間を 5 20 h と変化させたときの磁気特性を示したものである.この図 より, $\mathrm{H}_{\mathrm{cJ}}$ は時間の増加に伴い減少した。これも窒化処理 時間の増加に伴い $\alpha-(\mathrm{Fe}, \mathrm{Co})$ 相が多くなることが原因と思 われる.また $\sigma_{\mathrm{r}},(\mathrm{BH})_{\max }$ は窒化処理時間 $10 \mathrm{~h}$ のとき最高
值を示し, その後減少した. この結果より最適窒化処理時 間を $10 \mathrm{~h}$ とした。 以上より，最適作製条件を組成: $\mathrm{Sm}_{10}\left(\mathrm{Fe}_{0.9} \mathrm{Co}_{0.1}\right)_{88.7} \mathrm{Ti}_{0.3} \mathrm{Zr}_{0.5} \mathrm{Y}_{0.5}$, 熱処理条件: $660{ }^{\circ} \mathrm{C} \times 60 \mathrm{~min}$, 窒化処理条件: $420{ }^{\circ} \mathrm{C} \times 10 \mathrm{~h}$ とした.

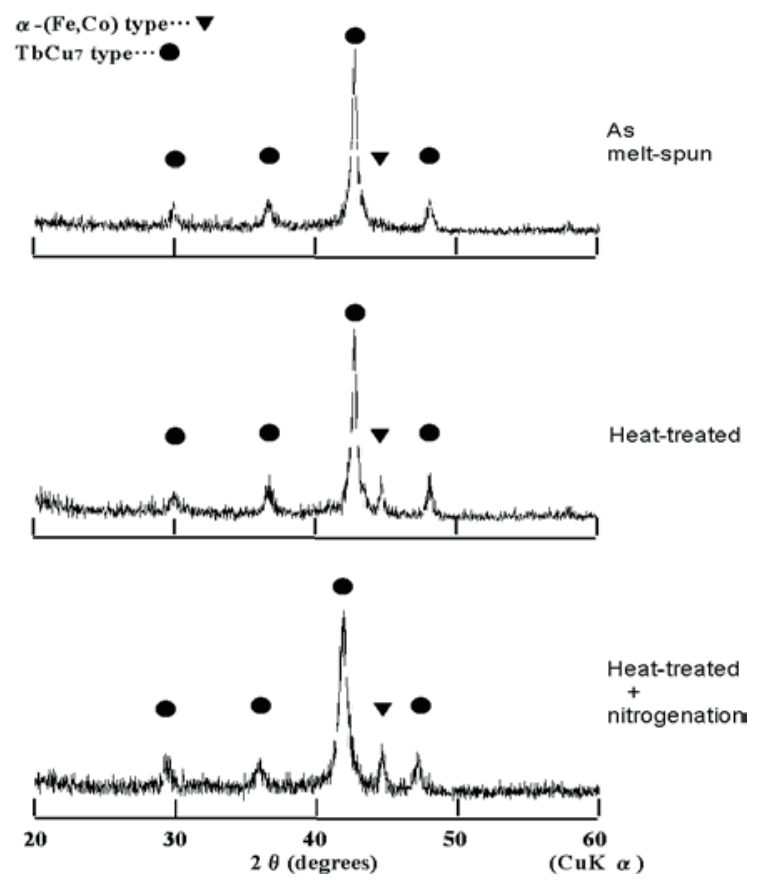

Fig. 6 X-ray diffraction patterns of $\mathrm{Sm}_{10}\left(\mathrm{Fe}_{0.9} \mathrm{Co}_{0.1}\right)_{88.7}$ $\mathrm{Ti}_{0.3} \mathrm{Zr}_{0.5} \mathrm{Y}_{0.5}\left(\mathrm{~N}_{\mathrm{x}}\right)$ compounds.

\section{2 窒化化合物磁石およびボンド磁石の諸特性}

Fig. 6 は, 最適組成の試料について急冷後, 熱処理後, 窒化処理後の X 線回折図を示したものである. 急冷後で は $\mathrm{TbCu}_{7}$ 型構造 $\mathrm{Sm}(\mathrm{Fe}, \mathrm{Co})_{7}$ 相が確認できた。熱処理後に は急冷後と比べ $\mathrm{TbCu}_{7}$ 型構造 $\mathrm{Sm}(\mathrm{Fe}, \mathrm{Co})_{7}$ 相と $\alpha-(\mathrm{Fe}, \mathrm{Co})$ 相 の成長が確認でき, 結晶化の進行が確認できた. 窒化処理 後では, $\mathrm{TbCu}_{7}$ 型構造 $\mathrm{Sm}(\mathrm{Fe}, \mathrm{Co})_{7}$ 相からのピークが低角度 側にシフトした.これは窒化処理により結晶格子間に窒素 が侵入し，結晶格子の間隔が伸びたためと考えられる.

Fig. 7 は最適組成の試料における, 急冷後, 熱処理後, 窒化処理後の $\sigma-\mathrm{T}$ 曲線を示したものである。試料は $4.8 \mathrm{MA} / \mathrm{m}$ でパルス着磁したのち, 印加磁界は $160 \mathrm{kA} / \mathrm{m}$ と して測定した. Fig. 6 の急冷後の X 線回折図からは明確に $\alpha-(\mathrm{Fe}, \mathrm{Co})$ 相が確認できなかったが， $\sigma-\mathrm{T}$ 曲線では見られた 理由として，X線回折では見られないが、 $\alpha-(\mathrm{Fe}, \mathrm{Co})$ 相が急 冷状態ですでに存在しているためと思われる. また $\mathrm{TbCu}_{7}$ 型構造 $\mathrm{Sm}(\mathrm{Fe}, \mathrm{Co})_{7}$ 相のキュリー温度は急冷後及び，熱処 理後では $358{ }^{\circ} \mathrm{C}$ であったのに対し, 窒化処理後では窒素侵 入により $\mathrm{Sm}(\mathrm{Fe}, \mathrm{Co})_{7}$ 相の窒化物のキュリー温度が $510{ }^{\circ} \mathrm{C}$ と約 $150{ }^{\circ} \mathrm{C}$ 上昇した。 以降 $800{ }^{\circ} \mathrm{C}$ 以上で $\alpha-(\mathrm{Fe}, \mathrm{Co})$ 相のキ ユリー点を示したことから, 窒化処理後の試料は $\mathrm{TbCu}_{7}$ 型構造 $\mathrm{Sm}(\mathrm{Fe}, \mathrm{Co})_{7}$ 相の窒化物と僅かに $\alpha-(\mathrm{Fe}, \mathrm{Co})$ 相を含む 二相であることがわかった。 
Table 1 Lattice constants of Sm-Fe-Co-Ti-Zr-(N) compounds.

\begin{tabular}{|c|c|c|c|c|c|}
\hline Composition & $\begin{array}{l}\text { Heat } \\
\text { treatment } \\
\text { condition }\end{array}$ & $\begin{array}{l}\text { Nitrogenation } \\
\text { condition }\end{array}$ & $\begin{array}{c}a \\
(\mathrm{~nm})\end{array}$ & $\begin{array}{c}c \\
(\mathrm{~nm})\end{array}$ & $c / a$ \\
\hline \multirow{2}{*}{ Sm10(Fe0.9Co0.1)88.7Ti0.3Zr0.5Y0.5 } & & & 0.489 & 0.420 & 0.859 \\
\hline & $\begin{array}{l}660^{\circ} \mathrm{C} \times \\
60 \mathrm{~min}\end{array}$ & & 0.489 & 0.420 & 0.859 \\
\hline$\{\mathrm{Sm} 10(\mathrm{Fe} 0.9 \mathrm{Co0} .1) 88.7 \mathrm{Ti} 0.3 \mathrm{Z}$ r0.5Y0.5 $\} 85.6 \mathrm{~N} 14.4$ & $\begin{array}{l}660^{\circ} \mathrm{CX} \\
60 \mathrm{~min}\end{array}$ & $\begin{array}{l}420^{\circ} \mathrm{CX} \\
10 \mathrm{~h}\end{array}$ & 0.500 & 0.425 & 0.850 \\
\hline
\end{tabular}
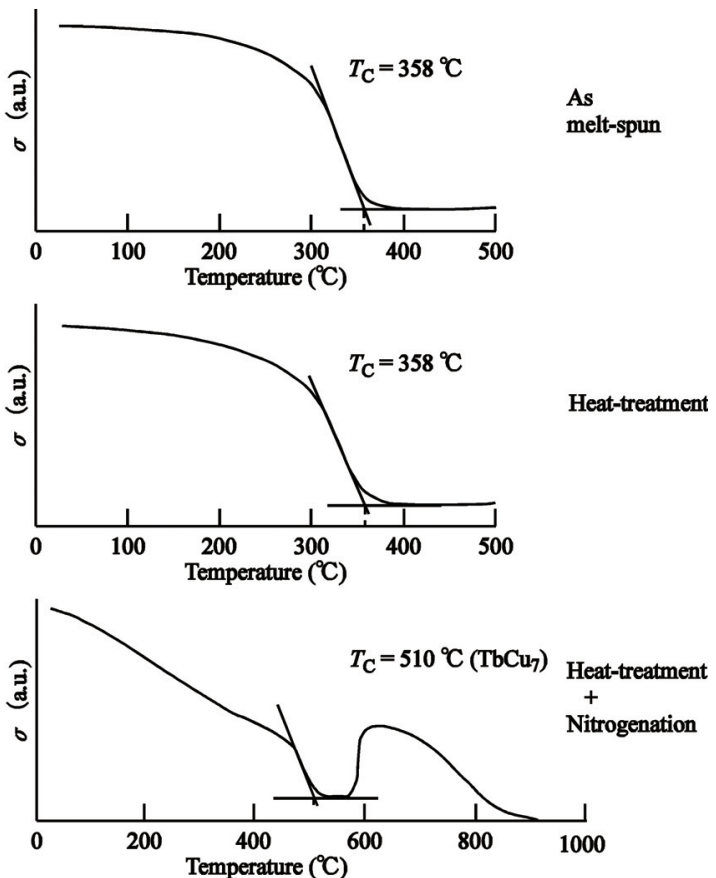

Fig. 7 $\sigma$ - $\mathrm{T}$ curves of $\mathrm{Sm}_{10}\left(\mathrm{Fe}_{0.9} \mathrm{Co}_{0.1}\right)_{88.7} \mathrm{Ti}_{0.3} \mathrm{Zr}_{0.5} \mathrm{Y}_{0.5}\left(\mathrm{~N}_{\mathrm{x}}\right)$ compounds.
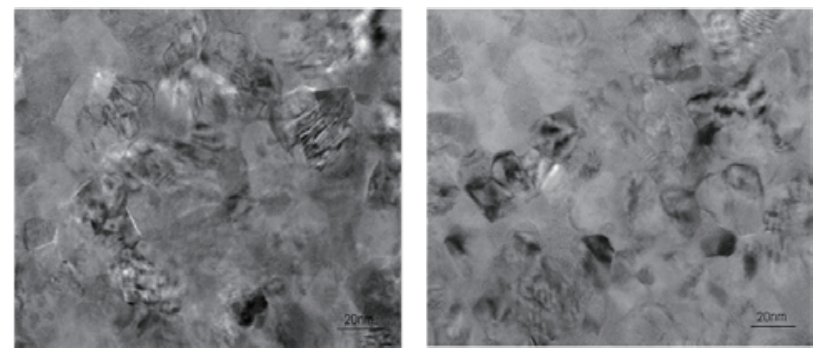

Fig. 8 TEM micrographs of $\mathrm{Sm}_{10}\left(\mathrm{Fe}_{0.9} \mathrm{Co}_{0.1}\right)_{89.2} \mathrm{Ti}_{0.3} \mathrm{Zr}_{0.5}$ and $\mathrm{Sm}_{10}\left(\mathrm{Fe}_{0.9} \mathrm{Co}_{0.1}\right)_{88.7} \mathrm{Ti}_{0.3} \mathrm{Zr}_{0.5} \mathrm{Y}_{0.5}$ ribbons. Heat-treatment condition: $660^{\circ} \mathrm{C} \times 60 \mathrm{~min}$, and nitrogenation condition: $420^{\circ} \mathrm{C}$ $\times 10 \mathrm{~h}$.

Table 1 は最適組成における急冷後, 熱処理後, 窒化処 理後の試料の格子定数を示したものである. 急冷後, 熱処 理後に比べ, 窒化処理後では $\mathrm{a}$ 軸, $\mathrm{c}$ 軸ともに格子間が伸 びていることが確認でき，また不活性ガス融解法により，
窒素量を分析したところ窒素量は 14.4 at \%であった。 以上 から窒素が侵入型で入っていることが確認された。

次に TEM 組織観察を行った。Fig. 8 はそれぞれ $\mathrm{Sm}_{10}\left(\mathrm{Fe}_{0.9} \mathrm{Co}_{0.1}\right)_{89.2} \mathrm{Ti}_{0.3} \mathrm{Zr}_{0.5}$ 組成, $\mathrm{Sm}_{10}\left(\mathrm{Fe}_{0.9} \mathrm{Co}_{0.1}\right)_{88.7} \mathrm{Ti}_{0.3} \mathrm{Zr}_{0.5}$ $\mathrm{Y}_{0.5}$ 組成で作製した急冷試料に熱処理条件を $660{ }^{\circ} \mathrm{C} \times 60$ min とで熱処理を施した試料の TEM 写真を示したもので ある。窒化物粉末は TEM 組織観察が困難であるため，今 回は熱処理後の試料をイオンエッチングで TEM 試料を作 製し組織観察を行った.この写真より両試料とも結晶構造 がナノオーダーで構成されていることが確認された.また 平均結晶粒径が, それぞれの試料の結晶粒径を約 200 個ず つ測定したところ $\mathrm{Sm}_{10}\left(\mathrm{Fe}_{0.9} \mathrm{Co}_{0.1}\right)_{89.2} \mathrm{Ti}_{0.3} \mathrm{Zr}_{0.5}$ 組成が 25.9 $\mathrm{nm}, \mathrm{Sm}_{10}\left(\mathrm{Fe}_{0.9} \mathrm{Co}_{0.1}\right)_{88.7} \mathrm{Ti}_{0.3} \mathrm{Zr}_{0.5} \mathrm{Y}_{0.5}$ 組成が $18.7 \mathrm{~nm}$ であっ た. Y 添加によって平均結晶粒径が小さくなっているため $\mathrm{H}_{\mathrm{cJ}}$ が増加したと思われる。

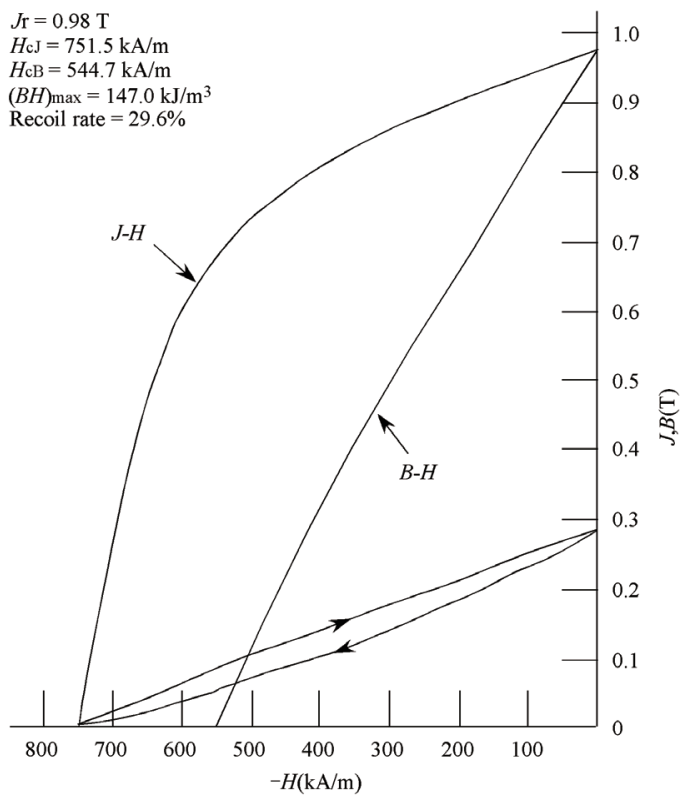

Fig. 9 Demagnetization curves and recoil loop of $\left\{\mathrm{Sm}_{10}\left(\mathrm{Fe}_{0.9} \mathrm{Co}_{0.1}\right)_{88.7} \mathrm{Ti}_{0.3} \mathrm{Zr}_{0.5} \mathrm{Y}_{0.5}\right\}_{85.6} \mathrm{~N}_{14.4}$ powder.

Fig. 9 は本実験において最高の磁気特性が得られた試料 
の粉末の減磁曲線とリコイル曲線を示したものである.こ の試料の磁気特性は $\mathrm{J}_{\mathrm{r}}=0.98 \mathrm{~T}, \mathrm{H}_{\mathrm{cJ}}=751.5 \mathrm{kA} / \mathrm{m},(\mathrm{BH})_{\max }=$ $147.0 \mathrm{~kJ} / \mathrm{m}^{3}$ (18.50 MGOe)であった. またこのとき, 保磁力 付近から磁界を 0 に戻したときのスプリングバック率は $29.6 \%$ であた. 以上より, 減磁曲線が単相を示している ことから, 硬質磁性相の $\mathrm{TbCu}_{7}$ 型構造 $\mathrm{Sm}(\mathrm{Fe}, \mathrm{Co})_{7}$ 相窒化 物之軟質磁性相の $\alpha-(\mathrm{Fe}, \mathrm{Co})$ 相が交換結合していると考え られる.さらにX線回析図, $\sigma$ - T曲線において 2 相であ る事, TEM 写真においてナノオーダーで組織が構成され ている事から,この試料は交換スプリング磁石であること が確認できた。

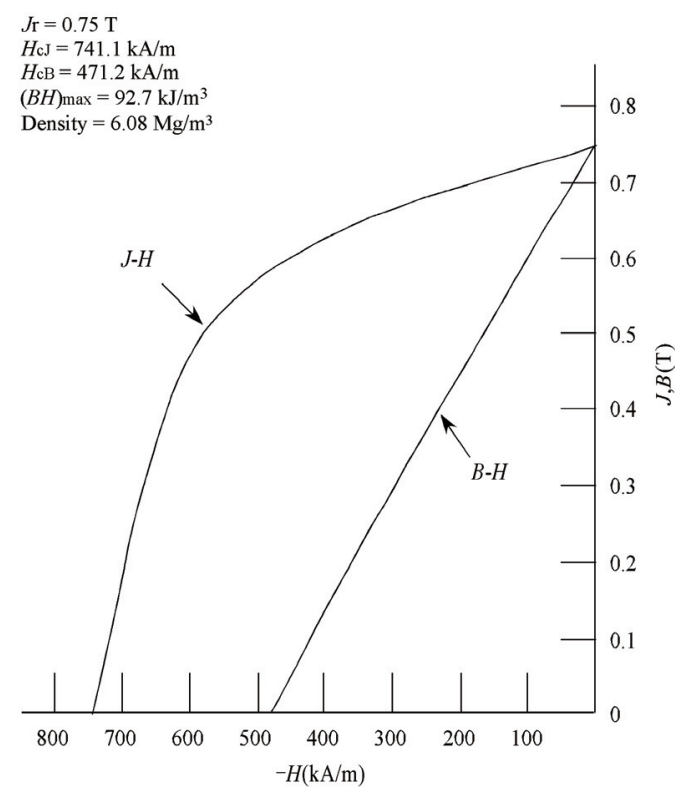

Fig. 10 Demagnetization curves of bonded magnet.

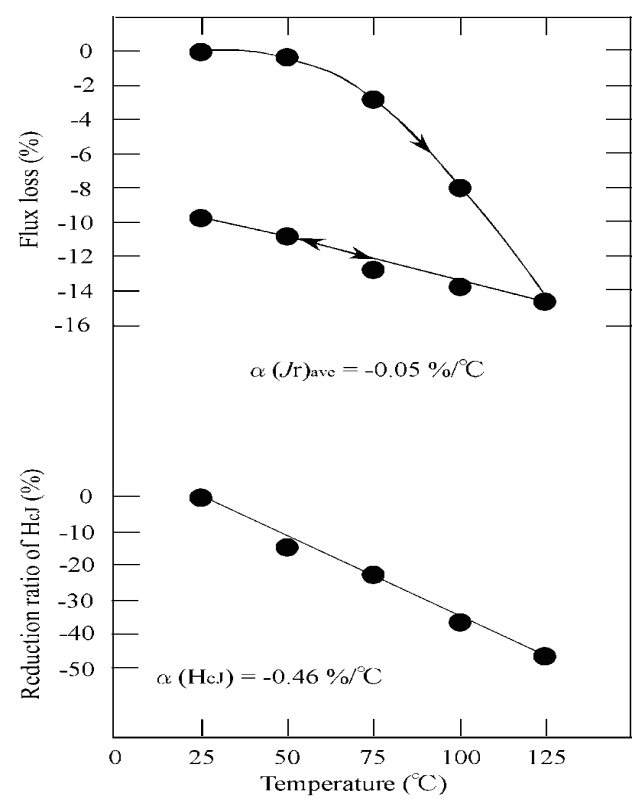

Fig. 11 Dependence of $\mathrm{Jr}$ and $\mathrm{HcJ}$ on temperature in $\left\{\mathrm{Sm}_{10}\left(\mathrm{Fe}_{0.9} \mathrm{Co}_{0.1}\right)_{88.7} \mathrm{Ti}_{0.3} \mathrm{Zr}_{0.5} \mathrm{Y}_{0.5}\right\}_{85.6} \mathrm{~N}_{14.4}$ bonded magnet.
Fig. 10 は最適組成において, 最適条件で処理した試料を 用いて作製した圧縮成形ボンド磁石の減磁曲線を示した ものである. 図よりこの試料の磁気特性は $\mathrm{J}_{\mathrm{r}}=0.75 \mathrm{~T}, \mathrm{H}_{\mathrm{cJ}}$ $=741.1 \mathrm{kA} / \mathrm{m}, \quad(\mathrm{BH})_{\max }=92.7 \mathrm{~kJ} / \mathrm{m}^{3}(11.7 \mathrm{MGOe})$ であった. このときの密度は $6.08 \mathrm{Mg} / \mathrm{m}^{3}$ であり, 良好な特性を示す ボンド磁石が得られた。

次に $\left\{\mathrm{Sm}_{10}\left(\mathrm{Fe}_{0.9} \mathrm{Co}_{0.1}\right)_{88.7} \mathrm{Ti}_{0.3} \mathrm{Zr}_{0.5} \mathrm{Y}_{0.5}\right\}_{85.6} \mathrm{~N}_{14.4}$ 化合物の $\mathrm{J}_{\mathrm{r}}$, $\mathrm{H}_{\mathrm{cJ}}$ について，25 125 ${ }^{\circ} \mathrm{C}$ まで温度を変化させたときの温度 特性を示したものをFig. 11に示す. 図より $\mathrm{J}_{\mathrm{r}}, \mathrm{H}_{\mathrm{cJ}}$ ともに温. 度上昇に伴い減少した。また $\mathrm{J}_{\mathrm{r}}$ の可逆温度係数は $\alpha\left(\mathrm{J}_{\mathrm{r}}\right)$ $=-0.05 \% /{ }^{\circ} \mathrm{C}, \mathrm{H}_{\mathrm{cJ}}$ の温度係数 $\alpha\left(\mathrm{H}_{\mathrm{cJ}}\right)=-0.46 \% /{ }^{\circ} \mathrm{C}$ であり, $\mathrm{Y}$ 添 加前の組成と比べほぼ同等の值であった。なお， $\alpha\left(\mathrm{H}_{\mathrm{cJ}}\right)$ は $25 \sim 125{ }^{\circ} \mathrm{C}$ の温度範囲において直線外挿から求めたもので ある。

\section{$3.3 \mathrm{Sm}-\mathrm{Fe}$ 系窒化化合物への $Y$ 添加効果}

著者らは先に Sm-Fe-Co-Cr 系化合物 11) と $\mathrm{Sm}-\mathrm{Fe}-\mathrm{Co}-\mathrm{Mn}-\mathrm{Ti}$ 系化合物 ${ }^{12)}$ に Y を添加し，窒化物を作製 したことを報告している。これらの結果，本実験と同様に Y を添加することにより, 無添加の組織に比べ結晶粒径が 小さくなっており，保磁力が上昇することが知られた.

本実験の Sm-Fe-Co-Ti-Zr 系化合物に Y を添加した窒化 物は, 先の我々の報告した $\mathrm{Sm}-\mathrm{Fe}-\mathrm{Co}-\mathrm{Cr}-\mathrm{Y}^{11)}$, Sm-Fe-Co-Mn-Ti-Y ${ }^{12)}$ 窒化物と同様に結晶粒径は小さくな っていた。最高の磁気特性が得られる条件は Y を添加す ることにより, 熱処理温度が $660^{\circ} \mathrm{C}$ と( $\mathrm{Y}$ 無添加の熱処理温 度 $700^{\circ} \mathrm{C}$ より)低くなり，(BH)max が 5\%向上し，保磁力は 本実験の最適条件と同じ条件で作製した Y 無添加窒化物 より 7\%向上した.

以上により, Sm-Fe 系合金への Y の添加効果は, 結晶 粒径微細化による保磁力向上であると確信できた。

\section{4. 結 言}

$\mathrm{Sm}_{10}\left(\mathrm{Fe}_{0.9} \mathrm{Co}_{0.1}\right)_{89.2-\mathrm{x}} \mathrm{Ti}_{0.3} \mathrm{Zr}_{0.5} \mathrm{Y}_{\mathrm{x}}$ 組成において, $\mathrm{Y}$ 量 $\mathrm{x}$ $=0 \sim 2.0$ at $\%$ と変化させた試料を急冷し, 熱処理, 窒化処理 をすることにより交換スプリング磁石を作製した.これら の磁気的, 物理的特性についてまとめた結果は以下の通り である.

1) $\mathrm{Sm}_{10}\left(\mathrm{Fe}_{0.9} \mathrm{Co}_{0.1}\right)_{89.2-\mathrm{x}} \mathrm{Ti}_{0.3} \mathrm{Zr}_{0.5} \mathrm{Y}_{\mathrm{x}}$ 組成において, $\mathrm{Y}$ 量 $\mathrm{x}=$ 0 2.0 at \%まで変化させ，それぞれの試料を周速度 $50 \mathrm{~m} / \mathrm{s}$ で急冷した試料の結晶構造は, $\mathrm{TbCu}_{7}$ 型構造 $\mathrm{Sm}(\mathrm{Fe}, \mathrm{Co})_{7}$ 相と $\alpha-(\mathrm{Fe}, \mathrm{Co})$ 相の 2 相であった.

2) $\mathrm{Sm}_{10}\left(\mathrm{Fe}_{0.9} \mathrm{Co}_{0.1}\right)_{88.7} \mathrm{Ti}_{0.3} \mathrm{Zr}_{0.5} \mathrm{Y}_{0.5}$ 組成において, 最適処理 を施した試料の $\sigma$ - T曲線により得た $\mathrm{TbCu}_{7}$ 型構造 $\mathrm{Sm}(\mathrm{Fe}, \mathrm{Co})_{7}$ 相窒化物のキュリー温度は $510{ }^{\circ} \mathrm{C}$ であり, 急冷 後の試料は $358{ }^{\circ} \mathrm{C}$ であった. 窒化処理後の試料では窒素侵 入によりキュリー温度が約 $150{ }^{\circ} \mathrm{C}$ 上昇することが確認さ れた。また, 窒素分析の結果より窒素 $\mathrm{N}$ は 14.4 at\%含有さ 
れていることが分かった。

3) $\mathrm{Sm}_{10}\left(\mathrm{Fe}_{0.9} \mathrm{Co}_{0.1}\right)_{89.2-\mathrm{x}} \mathrm{Ti}_{0.3} \mathrm{Zr}_{0.5} \mathrm{Y}_{\mathrm{x}}$ において $\mathrm{Y}$ 量 $\mathrm{x}=0$ 0 2.0 at $\%$ と変化させた時, $\mathrm{Y}$ 量 $\mathrm{x}=0.5 \mathrm{at} \%$ において良好な磁気 特性が得られ, 熱処理条件 $660{ }^{\circ} \mathrm{C} \times 60 \mathrm{~min}$, 窒化処理条件 $420{ }^{\circ} \mathrm{C} \times 10 \mathrm{~h}$ のときに最高の磁気特性を示した。 その值は $\mathrm{J}_{\mathrm{r}}=0.98 \mathrm{~T}, \mathrm{H}_{\mathrm{cJ}}=751.5 \mathrm{kA} / \mathrm{m}, \quad(\mathrm{BH})_{\max }=147.0 \mathrm{~kJ} / \mathrm{m}^{3}(18.50$ MGOe)であった。また、このとき保磁力付近から磁界を 0 に戻した時のスプリングバック率は $29.6 \%$ \%あり, 減磁曲 線, $\mathrm{X}$ 線回折図及び組織写真の結果の考察から交換スプリ ング磁石であることが確認された。

4) $\mathrm{Sm}_{10}\left(\mathrm{Fe}_{0.9} \mathrm{Co}_{0.1}\right)_{88.7} \mathrm{Ti}_{0.3} \mathrm{Zr}_{0.5} \mathrm{Y}_{0.5}$ 組成において, 最適条件 を施した窒化物を用いて作製したボンド磁石の磁気特性 は $\mathrm{J}_{\mathrm{r}}=0.75 \mathrm{~T}, \mathrm{H}_{\mathrm{cJ}}=741.1 \mathrm{kA} / \mathrm{m}, \quad(\mathrm{BH})_{\max }=92.7 \mathrm{~kJ} / \mathrm{m}^{3}(11.7$ MGOe)であり, この時の密度は $6.08 \mathrm{Mg} / \mathrm{m}^{3}$ であった。測 定結果より，このボンド磁石は高性能なボンド磁石である ことがわかった。また，このボンド磁石の $\mathrm{J}_{\mathrm{r}}$ と $\mathrm{H}_{\mathrm{cJ}}$ につい て、温度を $25 \sim 125^{\circ} \mathrm{C}$ と変化させた時の温度特性は, $\mathrm{J}_{\mathrm{r}}$ の可 逆温度係数 $\alpha\left(\mathrm{J}_{\mathrm{r}}\right)_{\mathrm{ave}}=-0.05 \% /{ }^{\circ} \mathrm{C}$ であり, $\mathrm{H}_{\mathrm{cJ}}$ の温度係数は直 線外挿で求めると $\alpha\left(\mathrm{H}_{\mathrm{cJ}}\right)=-0.46 \% /{ }^{\circ} \mathrm{C}$ であった。

\section{References}

1) M. Katter, J. Wecker, and L. Schultz: J. Appl. Phys., 70, 3188 (1991).

2) T. Yoneyama, T. Yamamoto, and T. Hidaka: Appl. Phys. Let., 67, 3197 (1995).
3) S. Suzuki, S. Suzuki, and H. Yamamoto: IEEE Trans. Magn., 31, 902 (1995).

4) S. Sakurada, A. Tsutai, T. Hirai, Y. Yanagida, and M. Sahashi: J.Appl.Phys, 79, 4611 (1996).

5) T. Yamamoto, T. Hidaka, T. Yoneyama, H. Nishio, and A. Fukuno: Materials Tans JIM, 37, 1232 (1996).

6) T. Hidaka, T. Yamamoto, N. Nakamura and A. Fukuno: $J$. Appl. Phys., 80, 1667 (1998).

7) A. Fukuno, T. Yamamoto, and T. Hidaka: J.Jpn. Soc. Powder powder Metal, 46, 581 (1999).

8) H. Yamamoto, S. Matsumoto and A. Fukuno: J.Jpn. Soc. Powder Powder Metal, 48, 184 (2001).

9) H. Yamamoto and T.Ooi: IEEE Trans. Magn., 40, 1952 (2004).

10) H. Yamamoto, and R. Nakamura: J.Magn.Soc., 29, 247 (2005).

11) H. Yamamoto and N. Mitani: .Jpn. Soc. Powder Powder Metal, 53, 590 (2006).

12) H.Yamamoto and K. Osanai: Jpn. Soc. Powder Powder Metal, 55, 522 (2008)

13) H.Yamamoto, K. Osanai, M. Tajima and F. Yamashita: Proc. of 20th International Workshop on Rare Earth Permanent Magnets, Crete., 406 (2008).

14) H.Fukunaga: The 120th Topical Symposium of the Magnetics Society of Japan, 15 (2001)

15) R. Fischer, T. Schrefl, H. Kronmuller, J. Magn. Magn. Master., 150, 329 (1995).

16) J. Bauer, M. Seeger, A. Zern, and H. Kronmuller: J. Appl. Phys., 80, 1667 (1996).

\section{9 年 10 月 16 日受理 2010 年1月 18 日再受理 2010 年03月17日採粶}

